\title{
Diabetes therapy boosts stem-cell campaign
}

\section{Paul Smaglik, Washington}

Recent successes in an experimental treatment for insulin-dependent diabetes are being used by some researchers to support their demands for federal funding of US research using human stem-cells.

The technique, known as the Edmonton Protocol, involves transplanting pancreatic tissue into the livers of diabetics. Devised by a team at the University of Alberta in Canada, the treatment gives the patients healthy islets - groups of cells in the pancreas that regulate blood sugar levels.

According to the researchers, eight patients who have received transplanted islets have not needed insulin therapy for up to 15 months. The results of the experiments will appear in the New England Journal of Medicine later this month, but have been released prior to publication because of their potential therapeutic importance.

Widespread use of the technique, however, is likely to require more tissue than can be derived from donors. To achieve therapeutic benefit, the University of Alberta scientists had to obtain islets from an average of two cadavers for every one patient treated.

Researchers, including the American Society for Cell Biology, argue that the potential demand for islets bolsters the case for federal funding of stem-cell research. Embryonic stem (ES) cells - if their growth and differentiation can be controlled might provide an effective substitute to the harvested islets.

Guidelines that would allow the US government to pay for research on ES cells are expected to be agreed by the end of summer. Legislation to expand that funding to the derivation of ES cells has also been proposed (see Nature 402, 566; 1999 and 405, 6; 2000).

The main supporters of such legislation, Senators Tom Harkin (Democrat, Iowa) and Arlen Specter (Republican, Pennsylvania), have previously used preliminary reports of the Edmonton Protocol's success to support their proposals for allowing the federal funding of stem-cell research.

Ray Rajotte, a University of Alberta endocrinologist who led the study, says that the effort needed to get islets from conventional sources underlines the need for alternatives. One technique could be to use growth factors or transgenic technology to steer stem cells in the pancreas, rather than ES cells, into becoming the insulin-producing beta cells that form part of the islets.

These 'adult' stem cells are likely to produce only a limited number of beta cells, says Allen Spiegel, director of the US National Institute of Diabetes and Digestive and Kidney Diseases. ES cells, which can divide for a longer period of time, could offer a better alternative.

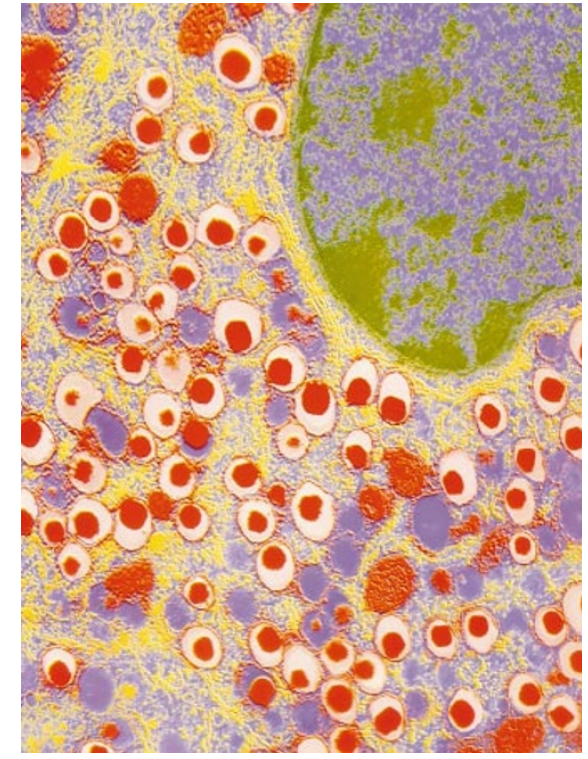

Growing up? Stem cells may offer an alternative to donor islet tissue (above) for treating diabetes.

But Rajotte warns against overoptimism for both the potential cellular engineering solutions, cautioning that ES and adult stemcells might not make up for an islet shortage. Although both can be grown into insulinproducing beta cells, he points out that islets also contain alpha cells, which secrete glucagon, as well as other cell types that, in concert, regulate blood sugar levels.

"We're not sure if the beta cell by itself will work," he says. But Spiegel points to new animal experiments that show beta cells by themselves could correct diabetes.

Previous islet transplantation attempts, which have been largely unsuccessful, used steroids to prevent patients from rejecting organs transplanted along with the islets. But although steroids help to protect the organs from immune responses, they damage the islets.

The Canadian team took several steps to lower the body's immune response. They treated the patients with antibodies to help reduce the production of immune cells, and did not culture the islets before transplantation, to avoid introducing foreign proteins.

An expanded trial of the Edmonton Protocol, funded by the US National Institutes of Health and the Juvenile Diabetes Foundation, will be carried out at ten research institutions in Canada, Switzerland, the United States and Germany over the next 18 months. About 40 patients will receive the treatment, which consists of a 20-minute infusion of the islets through a vein leading directly into the liver. The patients then take daily doses of oral immunosuppressive drugs.

| http://www.med.ualberta.ca/research/groups/islet

\section{Industry considers carbon catching}

\section{Steve Nadis, Boston}

While politicians look for economic and social solutions to global warming, industry is intrigued by the possibility of carbon sequestration - preventing carbon dioxide produced by burning fossil fuels from entering the atmosphere.

Earlier this month, the Massachusetts Institute of Technology's (MIT's) Energy Laboratory joined forces with six industrial partners to assess the options for sequestration. These include pumping carbon dioxide from power plants and factories into depleted oil and gas wells and the deep ocean, and planting trees to remove the gas from the atmosphere.

Through the newly formed Carbon Sequestration Initiative (CSI), MIT scientists and engineers will analyse various approaches, while also developing new ideas.

Current sponsors include Norsk Hydro from Norway, Total Fina Elf from France, and the US companies American Electric Power, the Ford Motor Company, General Motors and Texaco. More sponsors are

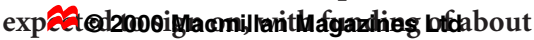
$\$ 250,000$ anticipated for the first year. The initial round of research projects will be decided at a sponsors meeting to be held at MIT in late October.

"This is not an effort to implement sequestration ideas," says CSI director Howard Herzog, an engineering researcher at MIT. "We're just trying to determine its potential and identify the key challenges, so that we can make informed decisions when the time comes."

Environmentalists are concerned that sequestration may distract from the goal of reducing dependence on fossil fuels.

"Techno-optimism about sequestration could dampen motivation to utilize energy efficiency and renewable energy on the scale we need to," says Peter Frumhoff, a specialist in global change at the Union of Concerned Scientists in Cambridge, Massachusetts.

But Herzog argues that sequestration could be a bridge "that lets us continue using fossil fuels while we develop acceptable alternatives". At the same time, he stresses that any strategies adopted must be environmentally sound. "We want to make sure we're not solving one problem by creating another," he says. 